\title{
PALB2 Mutation Analysis
}

National Cancer Institute

\section{Source}

National Cancer Institute. PALB2 Mutation Analysis. NCI Thesaurus. Code C157351.

A procedure used to detect and identify mutations in the PALB2 gene. 